\title{
Hamlet Between the Characters of Bukara and Učitelj/Teacher: On the Most Famous Play by Ivo Brešan
}

\author{
Helena Pericic \\ Department of Croatian Studies, University of Zadar, Zadar, Croatia
}

Email address:

hpericic@gmail.com

\section{To cite this article:}

Helena Pericic. Hamlet Between the Characters of Bukara and Učitelj/Teacher: On the Most Famous Play by Ivo Brešan. International Journal of Literature and Arts. Vol. 8, No. 4, 2020, pp. 217-223. doi: 10.11648/j.ijla.20200804.16

Received: February 21, 2020; Accepted: April 2, 2020; Published: June 15, 2020

\begin{abstract}
The paper discusses the most famous play written by the Croatian playwright Ivo Brešan /1936 - 2017/, which is based on Hamlet. The issue of representation, even defence of literary, aesthetic and ethical values comes up quite often in Brešan's plays on the grounds of an equal mechanism: between primitivism and brutality on the one side (following Hegel: Brešan's "Antithesis") and enlightenment and idealism on the other ("Thesis") there is a literary text as an extension of the Thesis; it is a template with a purpose to build up a new dramatic storytelling, which will be adjusted to spatial, social and philosophical circumstances to which the author belongs. A literary text in Brešan's plays functions as a mediator (be it Shakespeare's Hamlet or another play) and enters the zone of "popularization"; it has the role of an "arbiter" (Souriau) that emphasizes the values of the Thesis (the transfer between the scope of "serious" literature and reality) presented as a structure that should be made accessible to a wider audience, regardless of whether the receiver has recognized the mediator text or not. From the conscience of such a construction arise the questions on stratifications and goals of a transfer or "borrowing" from classic literature. We can conclude that the mediator text, in this case Shakespeare's Hamlet, with the milieu associated to it (Antithesis) together make Brešan's Synthesis, which turns into a new potential Thesis. A classic text that was meant for Elizabethan people throughout the centuries turned into an elitist canon of the educated and grew distant from its roots and its primary purpose of folk entertainment. In the $20^{\text {th }}$ century the same text receives a role of a highly valuable work of art, and the performance based upon it turns into an aesthetic event meant for the educated. Created and represented this way in Croatian playwriting during the 1960s and 1970s (in SFRY, i.e. former, communist Yugoslavia) - Shakespeare's text was used as a foundation for the construction of a new text, and this new text (as a reaction to the repression in the social system) - Brešan's The Stage Play of Hamlet in the Village of Mrduša Donja (today considered a classic play in Croatian literature) - is to be used by a future playwright for creating a new literary work, i.e. for a new intertextuality.
\end{abstract}

Keywords: Ivo Brešan, The Stage Play of Hamlet in the Village of Mrduša Donja, Croatian Drama, Former Yugoslavia, Ideology, Intertextuality, Reception

\section{Introduction: The Intertextuality of the Most Famous Play by Ivo Brešan [1]}

This paper - an expanded and updated version of the text published in 2018 among the proceedings of the conference Dani Hvarskog kazališta /The Days of Hvar Theatre/ attempts to give an insight into the intertextual concept represented in the Predstava Hamleta u selu Mrduša donja /The Stage Play of Hamlet in the Village of Mrduša Donja/ [2] that may be interpreted as a model key for understanding a structure of a considerable number of dramatic texts written by Ivo Brešan, Croatian playwright (Julije Cezar, Anera etc.), which the author calls grotesque tragedies. [3]

In this case a classic literary text has become a template and also a mediator to modernity - the factious/real and fictious/literary? Has that text been chosen as a material (or a "victim") in order to be transformed into a new text, or should it be interpreted as an unavoidable provocation that leads the contemporary author to an intertextual procedure in creating a new play? Moreover, has classical literature lost its importance or value? Or could it have achieved some new purpose? 


\section{Brešan's Theatre System}

We begin our discussion with the auto-referential essay "The Basic Principles of My Theatre System" (1996) by Ivo Brešan (deceased in January 2017, at the age of 81) which describes his commitment to drama as universal and timeless. Brešan states the following:

However, at all events, I am sure that the starting point of every work is an IDEA (capital letters in Brešan's original text, op. HP) and in this case, the idea is in conflict with itself, or it is a paradox in which incompatibles link, regardless of whether I have come to it by inspiration, intuition or something else. [4]

Following the umbrella theme of the conference: Folk and Popular [5], and trying to apply it to the paradox of the title of this paper, several aspects of the "folk" can be noticed in Brešan's dramatic work. I believe that these aspects can be categorized into two groups: the first would be formative, linguistic and stylistic, and the other may be considered motivational, semantic or ontological.

In Rječnik sinonima hrvatskoga jezika /Dictionary of Synonyms of the Croatian Language/ (ed. Ljiljana Šarić Wiebke Wittschen, Jesenski and Turk, Zagreb, 2008), the term "folk" is identified as "native", "indigenous", "unnoble", "popular", while "folkishness" is equated with "popularity".[6] However, such interpretation leaves out the characteristics of "folk" that tie it to the creativity of the collective, i.e. it is a creation which serves precisely that same collective. In his book Art Worlds Howard S. Becker explains this:

Folk art in this sense is the art made by people who do what they do because it is one of the things that are commonly done by members of their community, or at least most members of particular age and gender. [7]

\section{Ivo Brešan and Folk Theatre}

One of the possible aspects of the formative related to the characteristics of the folk is the genre view of Brešan's dramatic text as a folk performance piece. In his study, Marijan Bobinac emphasizes that Brešan's dramatic works such as The Stage Play of Hamlet in the village of Mrduša Donja are different from imitations of folk plays in artistic works of German, Austrian or some domestic, Croatian playwrights. Namely, in Brešan's The Stage Play of Hamlet there is, as Bobinac writes, "no admiration for the native land from traditional folk pieces":

/.../ everything, including the local community - earlier sacred in the eyes of its residents - has been reduced to the interests behind which money and power lie. Likewise, the harmless identification with the homeland is gone, and the harmonious relationship of the farmers/villagers with their surroundings also disappears. Very often, these "ordinary people" take the side of the local villain in his conflict with an outsider, usually with the embodiment of honesty and thus compromise the once self-evident authenticity of the native milieu. [8]
In other words, in many traditional folk plays and in the works of their followers of artistic dramatic expression, homeland has often been used as an excuse or alibi for the criminal acts of the local barons, the urge that the obvious evil and wickedness be neutralised by sentiment and the reader's immanent attachment to the romantically conceived "old homeland". Of course, we do not find this in Brešan. On the contrary, Brešan's story offers the above-mentioned "folkishness", in Becker's sense of belonging to the community collective, which presents a conflict of the individual with that community and the "ordinary people" (folk people; in Croatian: "puk").

Of course, the first formal-expressive group would include, among other things, the aspect of the characters using national, local or regional speech (here: "čakavian"/"chakavian" dialect and "ikavica" speech/pronunciation - from Dalmatian hinterland) to express themselves. The local idiom should also be mentioned here, which often manifests itself as the insertion of expressions, prop-phrases, jests, or verses that originated from the people or are a product of the playwright himself, who attempts to imitate the local speech. We know that there are many examples of this in The Stage Play of Hamlet in the Village of Morduša Donja, but one can also find them in other Brešan's plays or tragic-grotesques whose setting is not rural. In these plays, however, dialects and inserted expressions are used by some characters in contrast with the predominant representatives of the educated or, intellectual social stratum (an example of this is the "grotesque tragedy" of the Evil One at the Faculty of Philosophy or the "contemporary tragedy" of Julius Caesar). [9] Marijan Bobinac, in the earlier mentioned study on the relationship between Brešan and the tradition of Croatian folk play, states the following regarding the use of dialects in Brešan's plays:

Brešan demonstrates excellent skill in using a variety of dialects, not only Dalmatian ones, which are most frequently encountered, but also those from the broader area of Croatia, as well as other countries of the former Yugoslavia. This is primarily about his intention to be less ethnographic, folkloristically illustrative, and to pay more attention in his plays to the critical representation of the contradictions of social reality - with dramatic language playing a crucial role. (p. 201) [8]

On the other hand, however, there are the semantic and ontological aspects of the folk, which of course build on or intertwine with those mentioned above. I believe that within the ontological issue we can distinguish (sub) constituents of space, lifestyle, characters, storytime, as well as music - all of which are related to the notion of folk.

The space of the rural or of a small town/village (as opposed to the urban or metropolitan) in a large number of Brešan's grotesques results in the notion of urban being attached to whatever the broader urban environment conventionally represents. That is an average level of higher education of the population, intellectuality, elitism, art, sophistication, individuality etc., which of course need not be identified with ethically highly valued characteristics. 
Furthermore, the texts represent "folk" characters who originate mainly from provincial and rural areas and oppose the urban; the latter have very often the role of the protagonists. It is also possible to note here the confrontation between the lifestyles of these two environments, whereby a contrast between urban and rural culture is created, between the so-called high art versus folk, oral storytelling, oral literature in general, etc. Contrast is also made between the individual and the collective, and between the so-called civil, meaning courteous or sophisticated and, on the other side, uncivil, meaning vulgar and unsophisticated.

So urban and intellectual here do not represent the categories of "good" but in a way constitute a medium through which a contemporary culture that is universally accepted is reflected.

\section{Brešan's Idea of Thesis - Antithesis - Synthesis in Creating a New Play}

Namely, in the very play, The Stage Play of Hamlet in the Village of Mrduša Donja, the canonized or classical culture/literature and the simple population of a Dalmatianhinterland village are confronted in the decade immediately after the Second World War and in the time "certainly before the decisive 1948, while the Soviet-Ždanov model of the upbringing and cultural upliftment of people is incontestable and widely-spread", as Silvio Ferrari writes in his article "Native and European in Brešan's Tragic-grotesque: Arguments for the Paper". [10] The result of such an experience and endeavour in Brešan's plays is on the track of his reflection on Hegel, from whom the playwright learns that a "pure idea" (or idea "in itself" as a counterpart of Being) can be found in the great themes of classical literature because - what is represented in them is timeless, eternal, universal and thus fateful (p. 5) [4]. As a contrast to the use of that material stands the Antithesis found in everyday life and the banality of the Mrduša Donja locality, which in its harshness embodies everything that stands against the sublime, noble, and possibly of civilizational value. By combining the contradictions mentioned above, Brešan claims, a Synthesis is created.

Therefore, we can conclude that at the intersection of formative-expressive and motivational-ontological space, there stands the classical text itself. It combines the features of the first as well as the second space and, including fabular and stylistic features on one side and the conceptual and worldview layers of a "borrowed" text on the other; it represents an instrument for creating a Synthesis as a possible starting point for a new Thesis. In the blend of universal (pre-text) such as Shakespeare's Hamlet, its significance for literature and culture, and the naturalism of everyday life, the harshness and ruthlessness of Mrduša Donja - a Synthesis of Brešan's Elsinor and Mrduša is being built. Actually, in that way a new quality is produced; it is no longer either one or the other side, but "at the same time it involves both in itself" (p. 5) [4]. The local and the native are at the same time portrayed as inferior, subordinate to the "great world" and to world literature. However, one of the possible dilemmas is: does the local and the native, depicted in the way Brešan does, only seemingly appear inferior?

This brings us back to the questions posed in the beginning of this paper. The use of classical texts, their transformation into a dramatic fabric, intended as a stage performance for a theatrical, broader audience, is a way of converting elements of high culture, elite or "noble" into folk (that is a kind of an antonym). At the time of their appeareance Shakespeare's plays were not a medium of entertainment for the elite but for the wider and, on average, not particularly refined audience of the Shakespearean era.

For Brešan, the starting point is the experience of BEING (Brešan's capital letters, op. HP) that is alienated into its opposite - NOTHINGNESS, after which - as a Synthesis of Being and Nothingness - BEING will appear. According to Brešan, the real beginning is in the counterpart of Being, i.e., in the pure idea or the idea "in itself", in the Thesis phase: "Such an idea, which would have all attributes of the universal and fateful in a play, cannot be subjective, something arisen in the mind of an individual as his thought. It can only be something of a general nature, which is accepted as the cultural heritage of all humanity." (p. 5) [4]

Our playwright Ivo Brešan explains that the Thesis Antithesis - Synthesis triad has become to him "the basic roadmap for reflecting on a dramatic situation, and for the first time - in The Stage Play of Hamlet in the Village of Mrduša Donja". (p. 5) [4]

In his essay, Brešan further states:

The idea of "in itself" cannot, therefore, gain vitality or emanate the magic of the game if it is elaborated or modified within its own particularity (Ansichsein). It must become the idea of "for itself" (Fursichsein), come real in its opposite, as the being in nothingness, or, from the Thesis stage, move to the Antithesis. And its Antithesis can only be a transient and limited everyday life, recognizable as something "now" and "here" within one's reach. Practically, this means that the theme of Hamlet, from the mythically symbolic and also abstract Elsinor, should be taken to the abyss of the concrete, banal world of Mrduša Donja, while retaining all its formative elements and relations between them. This is how we get reality, which is Shakespearean in its main points but at the same time in its vulgar everydayness and caricature so opposed to itself that it fascinates precisely with its fall into otherness (Anderssein) and, as Škunca (Učitelj / Teacher, op. HP) says in the play, "it is so far from Shakespeare, that he may sleep peacefully in his grave". (p. 5) [13]

Based on the playwright's above interpretation of the relationship between thesis and antithesis, it can be concluded that opposite the Učitelj as a representative of Thesis, the figure of Bukara as his Antithesis, realized in the "caricature", "everyday", "concrete", and "banal" must be included in the story.

The use of classical work from, in this case, Elizabethan literature for The Stage Play of Hamlet or, e.g. for another Brešan's drama - Julius Caesar (1993), or the borrowing of 
Racine, Gogol, Goethe, and other classics in Brešan's opus indicates a confrontation or, as Brešan puts it: the "plunging" (Croatian: "strovaljivanje", HP) of such templates (the socalled hypo-texts) into the abyss of the concrete and banal world. When it comes to Mrduša Donja - it is "plunging" into a primitive and carnivalized rural environment where the local population learns about Shakespeare himself thanks to the theatre visit of their fellow villager Šimurina. In Julius Caesar, this happens based on an action set in 1990, in "a Croatian theatre", at the "time of the change of power" [11] (as Brešan writes it in the announcement of that dramatic text), which is, among actors and directors, the so-called scholarly world. [12]

However, Thesis and Antithesis form Synthesis, which is the final result of the process, in the part in which Elsinor and Mrduša Donja merge into the grotesque and become a "new quality" (Brešan). "In this way", our playwright explains, "we get the story of rehearsing an amateur play and a theft in the cooperative after which an innocent man is sent to prison. It is, therefore, a possible event somewhere in the seclusion of Dalmatian hinterland, in which Shakespearean relationships reveal a particular metaphysical vertical, creating a combination of the sublime and the trivial, the eternal and the transient, the fateful and the accidental, that is: BEING of the dramatic in the play." (p. 5) [4]

Brešan's relation to the theatre (which, for him, is an assumption of the relevance of a dramatic template because a dramatic text without its being put on stage has no purpose) stems from his belief that every real theatre is folk. In other words, the theatre aimed at the cultural elite - Brešan claims - makes no sense:

/.../ it is clear that any division of the theatre into "folk" and the one for the "chosen" audience is artificial and false. There is only theatre and what it is not, and theatre by its very definition is and can only be folk. And it has always been folk theatre, in all the great periods of its existence. (p. 12) [4]

In Brešan's view, Aeschylus, Sophocles, and Euripides, "who today have a halo of classics and academic models, were ordinary contestants at the time they lived, fighting for the affection of the audience in the amphitheatre". (p. 12) [4]

However, I believe that Brešan's experience of the "folkishness" of classical tragedies and his view that any division of the theatre into "folk" and the one for the "chosen" audience is artificial and false - should be taken with restraint because Greek tragedy as "folk" was valued at the time when the authors lived, while in modern times it represents the canon of the contemporary elite, which Brešan himself admits. [13]

In the above-mentioned essay, Brešan writes that in his dramatic creation he wanted to write a play that would have a comprehensive approach to reality, such as a philosophical system, and would still remain at the level of theatrical representation and the plot. (p. 3) [4] Nevertheles, "/.../ all such efforts resulted in some hybrid creations, which had to sacrifice all that makes philosophy a philosophy and all that makes a theatre because the reality in them was impoverished to abstraction and philosophy shrunk to mere rhetoric". (p. 7) [4]

I refer here to another intertextual situation in the plays of Ivo Brešan: a classic, anthological dramatic work that served as a template for the emergence of Brešan's world and as a bridge between the two worlds (in this case: urban, educated, intellectual, etc. opposed to rural, native, intellectually and spiritually "subordinate") is manifested in his plays in two ways. The first way is that this link is incorporated into Brešan's new text itself, hyper-text, in which we discern the outlines of the text that preceded it, and perceive this new one as a kind of palimpsest. The second but frequent way of "borrowing" classics in Brešan's tragic-grotesques is manifested in the fact that the work that served as a template or pre-text is inserted in a new text in the form of "theatre in theatre" (such examples are found in The Stage Play of Hamlet... and in Julius Caesar's - with a dramatic action located in the theatre where Shakespeare's Julius Caesar is staged.). In both examples, the plays are staged under their original titles and the relationship to the "bridge" text is explicit.

\section{5. (Non-) Political Engagement of Brešan's Play}

In the autumn of 2013, an interview with Brešan took place at the City Library in Biograd (a Croatian town on the Adriatic coast, in Dalmatia). The organizers wanted to present to the broader audience the full opus (plays and novels) of Ivo Brešan. [14] In this and some other public appearances, the author was able to deny the political engagement of his dramas, acknowledging, however, that escaping from politics is still political engagement.

After all, Brešan himself says in his text that "Every genuine art is at the same time politically engaged, which need not be specifically proven, even when it avoids being involved in any kind of politics, it is in it because the escape from politics is also a political engagement". (p. 8) [4] (It seems that some other Croatian writers are also known to have denied a political involvement of their texts in the 1960s. (e.g. Antun Šoljan /1932-1993/, who did not acknowledge the political dimension of his novel, A Short Trip /original title, Kratki izlet/). If we follow Brešan's definition of a work of art as a product free of private interest or general interest (especially of a political nature) - thus, provided that, in simple words: to write means not to be a politician - we conclude that the consequence of the literary work itself is the enjoyment offered to everyone equally, regardless of the author's possible political beliefs, but also irrespective of the potential political rootedness of the text in the particular milieu from which it emerges.

In one of his interviews (1985), Brešan states: "I do not really care about politics in theatre. Namely, I only care about it as much as it is part of life. The subject of my interest is what has always been a subject of interest of writers: human wrongs and, on the other hand, human idealism, which is 
defeated in the fight against corruption, thievery... /... Politics is never an aspect of observing things here, /.../, but the object of observation. After all, it's always been the case." [15] Thus, his drama, Julius Caesar, which appeared relatively shortly after the establishment of the new Croatian state, in the early 1990s, is a bold criticism of the political and ideological circumstances of the time.

As the Antithesis of the idealism of Učitelj/Teacher Škunca, there is "our", small-village political "sheriff", great and durable, constant Bukara, who, let us say, from the time of the Renaissance comedies, looks at us - our space and time - in the eye and touches us with the smile of a "crafty fellow" sensing that on the political stage he will outsmart the city (or civic) opponents, who are not his genuine opponents because they lack his uncompromising quality and "thick skin", and because there are many more of "his pals" or those who are on the side of everything that Bukara represents and stands for (primitivism, self-interest and robbery, and ideological respression in the social communist - system in the former Yugoslavia, i.e. SFRY, in the decades after the World War II).

The Antithesis understood in Brešan's terms seems to become predominant with the flow of events in the play; Antithesis and Thesis merge eventually into Brešan's desired Synthesis; social, moral monstrosity and disorder seem to become a (desirable) average and the normal. The Teacher himself turns into an unacceptable weirdo condemned to compromise, which is evident in the Teacher's adaptation of Shakespeare's text to the environment in which the play is being performed - the village of Mrduša Donja.

At the very end of the play, Bukara exclaims, "Who's turned off the light?", and the Teacher shouts: "Turn on the light!". In contrast to Bukara - whom we recognize today as a small-town power-wielder and sponsor of cultural events with expensive sunglasses with extremely dark lenses stands the Teacher, a polite, sensitive intellectual who represents universal literature and culture, and teaches "the folk". What he does (with Shakespeare's play) seems so far from the original text - Škunca consoles himself. He is certain that by staging the play of the English bard in the primitive surroundings of Mrduša - he himself, the Teacher, in relation to the great playwright - does not make any sacrilege. However, an interesting detail is a replica of Škunca himself, uttered before the light was finally turned off at the end of the drama. Namely, when Joco Škoko begs Teacher Škunca for help and the defence of the honor of his accused but innocent father, that very Teacher, whom we perceive as a reasoner, the moral counter-balance to Bukara and a conciliator, frightfully shouts: "Sorry Joco... You know it yourself. I stay out of everything. It's none of my business..." (p. 57) [2]. Those words put the Teacher Škunca into the "opportunistic collective", and the politics of "nonrocking-the boat", a frightening and often disastrous combination of politics, power, repression, but also of the indifference of the majority. I would say that by that detail, often overlooked, Brešan warns us about the layered nature of this benevolent Teacher.

\section{Conclusion: Brešan's The Stage Play of Hamlet... as a New Potential Thesis}

The issue of the representation and defence of (literary, aesthetic, ethical, etc.) values often arises in Brešan's dramatic opus based on a similar mechanism: between primitivism, hypocrisy, cruelty, brutality, and potential and actual offence, and even crime on the one hand (Brešan's Antithesis), and enlightenment, progressiveness/progress and idealism (Thesis) on the other there is a literary (pre-) text. It stands as an extension of the Thesis, i.e. a more or less obvious/disguised template the purpose of which is to construct a new dramatic narrative thematically and fabulawise, adapted to the spatial, social and world-view circumstances to which the author himself belongs. The mediating, "bridge" literary text in Brešan's plays (either Shakespeare's Hamlet or Julius Caesar, Racine's Anera or Gogol's Auditor) thus enters the "popularization" zone because with its role as a transferrer (as Souriau would call it: "arbiter") that emphasizes the values of the Thesis, the transfer between the sphere of "great literature" and reality is being presented as material that should be made close to the wider public. In other words, the hypo-text, pre-text becomes close to the one who receives the final dramatic text (whether he/she reads it or watches it on stage), regardless of whether the recipient has recognized that "bridge" text and "deciphered" it. Awareness of this and such construction poses questions, among other things, about the layering and purpose of such a transfer or "classic borrowing." It can be concluded that the mediating text (in this case Shakespeare's Hamlet ) together with the milieu to which it is attached (Antithesis) represent the means (Thesis), which is on the way to Brešan's mentioned Synthesis, and this Synthesis in turn creates a new potential Thesis. The classic text (that was once intended for the Elizabethan people) has through the centuries been transformed into an elitist canon of the educated, moving away from its roots and the original purpose of popular entertainment, education etc. The same text, however, in the 20th century takes on the role of a highvalue work of art and the performance based on it becomes an aesthetic act intended for an educated audience. Conceived in such a manner and presented in the practice of writing drama in Croatian literature of the late 1960s and early 1970 s - Shakespeare's text was used as the basis for the construction of the new, and this new text - Brešan's The Stage Play of Hamlet - as we know, has become a classic and probably the most famous work of Croatian dramatic literature. However, Brešan's play might be at the same time a potential template for a new The Stage Play of Hamlet in the Village of Mrduša Donja to be written by a future playwright who would use now already a dramatic classic of Croatian literature (Brešan's drama) for transforming it into a new text and for the means of new intertextuality. In this new intertextual practice, it is possible that the canonized literary value (as a basis for the new text) will in fact be the subject of questioning and skepticism. Namely, that scepticism seems to have already been announced in Brešan's view on 
the history of civilization and history of literature. However, that is perhaps another issue related to Brešan's opus and it would probably be worth exploring. [16]

In Midsummer Night's Dream, the famous story of Pyramus and Thisbe is a pattern for a performance rehearsed by a group of tradesmen who from the ancient Mesopotamian and then from Ovid's Metamorphoses story make an object of ridicule and mockery, but also a means of making the audience of their time laugh. Following this trace roughly four centuries later, Shakespeare's Hamlet becomes a template for a play rehearsed by comparatively simple and down-to-earth "actors" in the milieu of an imaginary village in a poor Dalmatian dreary place. However, besides the purpose that the tradesmen's staging in Shakespeare's Dream had in relation to the viewers, besides the corresponding use that tragedy of Hamlet has in Brešan's play, here, in the wake of the Hegelian Thesis and Antithesis, to which Brešan refers, a vital role opens up. Shakespeare's Hamlet plays this role of "Mousetrap" in Brešan's The Stage Play of Hamlet in the Village of Mrduša Donja Shakespeare's Hamlet. Alike "Mousetrap" and the actors in Shakespeare's play who reveal Claudius as a villain, Shakespeare's play in Brešan's drama becomes a mechanism of raising awareness of the viewers' attitude towards "the wrongs" and "the rights" in the play (as it is a mechanism of raising awarness of the audience shown in the play itself). Therefore, there is a kind of trap in which both Mrduša locals and the audience in the Brešan's play are caught, bearing witness to the performance directed by the Teacher Škunca and performed by Bukara, Puljo, Anđa and others. However, in our case, the mechanism of the "Mousetrap" has its purpose for those who view Brešan's play; therefore, it assumes universal importance. I believe that this mechanism is applicable both to the space and time of origin of Brešan's tragic-grotesque (written half a century ago) and to our area and age. Therefore, the use of a classical drama as a template for social and political provocation aimed at revealing truth and guilt that is Claudius' as well as ours - is definitely and unfortunately - relevant.

\section{Acknowledgements}

The author of this paper Helena Pericic (Peričić) thanks the anonymous reviewers of the manuscript for their valuable comments, as well as some of her colleagues for their suggestions in the process of translating this paper into English.

\section{References}

[1] In Ivo Brešan's /Brešan - pronounced as "breshan"/ play The Stage Play of Hamlet in the Village of Mrduša Donja there are characters Učitelj Škunca and Bukara. Croatian word učitelj means teacher in English, and Bukara (nickname) is related to the Croatian noun meaning a big wooden pot for drinking wine (that may contain several litres of liquid); in English it could be translated as jug, although a derived Croatian word bukačenje has the basic meaning of creating noise and has some erotic connotations as well.
[2] Brešan, I. (1998). Predstava Hamleta u selu Mrduša Donja /The Stage Play of Hamlet in the Village Mrduša Donja/. SysPrint.

[3] The author of this paper, Helena Peričić, discusses the issues of intertextuality in the Croatian drama of the second half of the 20th century in her books: Peričić, H. (2008). Tekst, izvedba, odjek (Trinaest studija iz hrvatske i inozemne dramske književnosti )/Text, Performance, Echo: Thirteen Studies on Croatian and Foreign Dramatic Literature/. Erasmus; and in: Peričić, H. (2011). Deset drskih studija (o književnim pitanjima, pojavnostima i sudbinama) /Ten Insolent Studies: on Literary Problems, Manifestations and Destinies/. Naklada Bošković.

[4] Brešan, I. (1996). Osnovna načela moga kazališnog sustava /The Basic Principles of My Theatre System/, Republika (literary review published by Društvo hrvatskih književnika DHK/Association of Croatian Writers/), Zagreb, 52 (1-2), 7. Original text in Croatian: "No, bilo kako bilo, siguran sam da je polazna točka svakog djela IDEJA, a u ovom mom slučaju u konfliktu sa samim sobom, ili paradoks, u kom se spaja nespojivo, bez obzira jesam li do toga došao nadahnućem, intuicijom ili čim drugim."

[5] The paper was presented at the annual conference Dani Hvarskog kazališta /Days of the Hvar Theatre/ in 2017; the topic was "Pučko i popularno" /Folk and Popular/. NOTE: In 1612 the city of Hvar on the Croatian island of Hvar obtained a public - communal theatre for the use of all its citizens regardless of social class status. In that way the Hvar Theatre entered the history of European theatre.

[6] Šarić. Lj. - Wittschen, W. (2008). Rječnik sinonima hrvatskoga jezika /The Dictionary of Synonyms in Croatian/, Jesenski and Turk, 863.

[7] Becker, H. S. (2009). Svjetovi umjetnosti (Dopunjeno i prošireno izdanje) /orig. Art Worlds, Updated and Expanded/, transl. into Croatian by Hana Dvornik and Srđan Dvornik, (Publisher) Jesenski and Turk, 265. Here H. Peričić uses the the translation from the Croatian edition: "Pučka je umjetnost $\mathrm{u}$ tom smislu umjetnost koju izrađuju ljudi koji čine to što čine jer je to jedna od stvari što ih uobičajeno čine pripadnici njihove zajednice, ili barem većina pripadnika određene dobi i spola."

[8] Bobinac, M. (1993). I. Brešan i tradicija hrvatskoga pučkog komada /I. Brešan and the tradition of Croatian Folk Play/, Republika, 37 (3-4), 198. Original text in Croatian: "/.../ sve, pa i lokalna sredina - ranije svetinja u očima njezinih stanovnika - svedeno je na interese iza kojih se kriju moć $i$ novac. Nestaje, jednako tako, i bezazlenog poistovjećivanja sa zavičajnim, nestaje i harmoničkoga suodnosa seljaka/malomještana s njihovim okružjem. Nerijetko i ti 'mali ljudi' staju na stranu mjesnoga silnika u njegovu sukobu s outsiderom, obično utjelovljenjem čestitosti, i na taj način kompromitiraju nekada samorazumljivu nepatvorenost zavičajnog milieua."

[9] On several occasions, talking about Brešan's play The Stage Play of Hamlet in the Village of Mrduša Donja, Helena Peričić discussed the issues of the introduction of the vernacular and the difficulty of its translation, e.g. into English either as the dramatic text (or its fragments) or the translation in a film based on Brešan's dramatic pattern, like in the case of Krsto Papić's film Predstava Hamleta u Mrduši Donjoj (the English translation of the title was: Acting of Hamlet in Mrduša Donja) from 1973. 
[10] Ferrari, S. (2004). Zavičajno i europsko u Brešanovoj tragigroteski (argumenti za referat) /Native and European in Brešan's Tragic-grotesque: Arguments for the Paper/, Republika, 60 (12), 82.

[11] Brešan, I. Julius Caesar, in: Brešan, I. (1997). Spletke /Intrigues/. Hrvatsko slovo, 165.

[12] Cf. Peričić, H. (2006). Dodiri antike i suvremenosti na primjerima hrvatske drame druge polovice XX. stoljeća /The Connections of the Classic and the Modern in the Examples from Croatian Drama in the Second Half of the 20th Century/, Komparativna povijest hrvatske književnosti. /Collection of Papers: Croatian Literature vs. European Literature (Emision and Reception) 1940-1970/, ed. Cvijeta Pavlović and Vinka Glunčić-Bužančić, Književni krug, 8, 393-404; or in Peričić, H. (2008). Tekst, izvedba, odjek (Trinaest studija iz hrvatske $\mathrm{i}$ inozemne dramske književnosti) /Text, Performance, Echo: Thirteen Studies on Croatian and Foreign Dramatic Literature/. Erasmus, 109-120.

[13] Cf. Bobinac, M. (2001). Poetika i dramska praksa Ive Brešana /Poetics and Dramatic Practice of Ivo Brešan/. Republika, 57 (9-11), 62.

[14] The author of the paper; Helena Peričić, was privileged to be the moderator of the discussion.
[15] Brešan, I. (1985). Intervju: "Provincija nije geografski smještena, već se nalazi u glavama ljudi" /Intervew with Ivo Brešan: Province is not geographically located, but is in the minds of the people/. Original text in Croatian: "Mene politika, zapravo, ne zanima u teatru. Odnosno zanima me samo toliko koliko je dio života. Predmet mog interesa jest ono što je piscima oduvijek bio predmet interesa! To su ljudske naopakosti i, s druge strane, ljudski idealizam koji doživljava poraz u borbi protiv pokvarenost, lopovluka... /.../ Politika tu nije nikada aspekt promatranja stvari, /.../, nego je ona objekt promatranja. Uostalom, to je tako uvijek i bilo." http://www.yugopapir.com/2017/01/ivo-bresan-intervjuprovincija-nije.html.

[16] Perković, V. (2017). Demitologiziranje hrvatske povijesti s pozicija sadašnje skepse prema njezinu kontinuitetu klimavost dramske konstrukcije /Demythologization of Croatian History from the Point of View of Present Skepticism towards its Continuity - the Shakiness of Dramatic Construction/, in: Perković, V. (2017). Stvarnost i umjetnička stvarnost djela (S pogledom na suvremenu hrvatsku dramatiku) /Reality and Artistict Reality of a Work: with the View on Contemporary Croatian Drama/. Naklada Bošković, 149. 